\title{
Heavy Metal Concentrations in Muscle, Liver and Kidney Tissue of Striped Dolphin, Stenella coeruleoalba, and Their Variations with Body Length, Weight, Age and Sex
}

\author{
Katsuhisa Honda, Ryo Tatsukawa, Kazuomi Itano,* \\ Nobuyuki MiYAZAKI** and Toraya FujIYAMA*** \\ Department of Environment Conservation, Ehime University, \\ Tarumi 3-5-7, Matsuyama 790, Japan \\ * Department of Food Chemistry, Osaka City Institute \\ of Public Health and Environmental Sciences, \\ Tojo-cho 8-34, Tennoji-ku, Osaka 543, Japan \\ **National Science Museum, Hyakunin-cho 3-23-1, \\ Shinjuku-ku, Tokyo 160, Japan \\ ***Department of Marine Science, University of the Ryukyus, \\ Nishibara-cho, Senbara 1, Okinawa 903-01, Japan
}

Received July 26, 1982

\begin{abstract}
The concentrations of $\mathrm{Fe}, \mathrm{Mn}, \mathrm{Zn}, \mathrm{Cu}, \mathrm{Pb}, \mathrm{Ni}, \mathrm{Cd}$ and $\mathrm{Hg}$ in the muscle, liver and kidney of fifty nine striped dolphins captured during 1977 1980 were determined by atomic absorption spectrophotometry. The levels of most the metals examined were higher in the liver than the other tissues, except for the highest renal $\mathrm{Cd}$. The frequency distribution of the metal concentrations was mostly log-normal. For all of the organs, correlation of the metal concentrations to the body length, weight and age was positive for $\mathrm{Fe}, \mathrm{Pb}, \mathrm{Ni}, \mathrm{Cd}$ and $\mathrm{Hg}$, and negative for $\mathrm{Mn}, \mathrm{Zn}$ and $\mathrm{Cu}$. A higher correlation of the concentrations of $\mathrm{Fe}, \mathrm{Mn}, \mathrm{Zn}$ and $\mathrm{Cu}$ to the body length and weight than to the age indicates that the metabolic turnover is more important than age or exposure time in determining the levels of those metals. Whilst the concentration of $\mathrm{Pb}, \mathrm{Ni}, \mathrm{Cd}$ and $\mathrm{Hg}$ correlated closely with the age of dolphins, and this suggests that the age or exposure time is a dominant factor for accumulation of these metals.

The concentrations of $\mathrm{Pb}, \mathrm{Ni}, \mathrm{Cd}$ and $\mathrm{Hg}$ in the muscle, liver and kidney increased with age until 1 year, leveled off through 1 to 18 years by physical dilution with increased body weight, and thereafter steadily increased year by year, but in case of $\mathrm{Hg}$ such physical dilution effects were not significant. Relatively wide variation of the metal concentrations in the pup and $8 \sim 25$ years females was probably due to the effects of suckling, and of parturition and lactation, respectively.
\end{abstract}

The accumulation of heavy metals in marine organisms has increasingly drawn attention because of heavy metal pollution in the marine environment. In particular, mercury which caused "Minamata disease" is known to be highly concentrated in top predators in the marine food chain such as seal, dolphin, tuna, swordfish and shark. It is one of the main concerns among environmental scientists to elucidate the origin and mechanism of mercury accumulation in these species. The mercury and the other heavy metal concentrations in marine mammals have been extensively studied by many workers for various species in different localities. ${ }^{1 \sim 17)}$ The nature of tissue or organs, size and age of animals, and season or locality for sample collection are very critical for the investigation of large animals such as marine mammals. However, a detailed analysis of tissue and organ distribution of metals and their variation with age, sex, reproductive activities and season largely remained to be studied.

Among marine mammals, the striped dolphin, Stenella coeruleoalba, which predominantly feed on squid, myctophid fishes and 
shrimp, is an abundant and important component of the upper part of the pelagic food web surrounding Japan. ${ }^{18)}$ Since it is a longliving marine mammal, i.e. more than 40 years, the animal is useful as an "indicator species" to learn complex long-term accumulation characteristics of heavy metals in the marine environment.

We have already reported the distribution characteristics of heavy metals in bone, blubber and skin of the striped dolphin, and the nature of the organ(s) of dolphins to be selected for ecological and hygienic comparison was discussed. ${ }^{23)}$

The main objectives of this paper, therefore, are as follows: (1) the measurement of metal levels in muscle, liver and kidney, (2) the variation and frequency distribution of these metal concentrations and (3) the relationship between metal concentration, body length, weight, age and sex. The heavy metals studied were $\mathrm{Fe}, \mathrm{Mn}, \mathrm{Zn}, \mathrm{Cu}, \mathrm{Pb}, \mathrm{Ni}, \mathrm{Cd}$ and $\mathrm{Hg}$.

\section{MATERIALS AND METHODS}

Fifty nine striped dolphins were captured alive at Kawana on the east coast of the Izu Peninsula in December 1977, and at Taiji on the southern tip of the Kii Peninsula during the winter open seasons in December $1978 \sim 1980$. Since the animals are seasonal migrators, the open season in these areas is between October and January. ${ }^{19)}$ All specimens appeared to be in a good healthy condition, with no macroscopic pathological symptoms. The animals were frozen at $-20^{\circ} \mathrm{C}$ as soon as field conditions permitted $(1 \sim 8 \mathrm{hr})$.

Body length, weight, sex and basic morphometric data were recorded for all specimens. The mandibular teeth were taken from each animal and were aged from the dentinal growth layers following the methods of Kasuya $e t$ $a l^{20)}$ After detailed anatomy, the weight of various organs and tissues was measured and recorded, and these data with the relevant biometrics have already been reported by Miyazaki et al. ${ }^{22)}$ Representative muscle samples for metal determination were taken from a site about $10 \mathrm{~cm}$ in width under the dorsal fin, as described by Honda et al. ${ }^{23)}$ Liver samples were excised from the medio-lateral lobe; samples of kidney were from medio-lateral region of the left kidney. These samples were packed in polyethylene bags and kept frozen at $-20^{\circ} \mathrm{C}$ until analysis.

One to ten grams of tissue from each sample were digested with a concentrated sulfuric, nitric and perchloric acid mixture. Measurements of the heavy metals (Fe, Mn,
$\mathrm{Zn}, \mathrm{Cu}, \mathrm{Pb}, \mathrm{Ni}$ and $\mathrm{Cd}$ ) were performed by atomic absorption spectrophotometry, and the concentration of $\mathrm{Hg}$ was determined by flameless atomic absorption spectrophotometry.

\section{RESULTS AND DISCUSSION}

\section{Metal levels in muscle, liver and kidney}

Table I shows the mean concentration of heavy metals $(\mu \mathrm{g} /$ wet $\mathrm{g})$ in muslce, liver and kidney of the striped dolphin. The level of the metals examined was generally higher in the liver than the other tissues, and markedly so for $\mathrm{Hg}$. The highest level of $\mathrm{Cd}$, however, was in the kidney where the mean concentration $(24.8 \mu \mathrm{g} / \mathrm{wet} \mathrm{g})$ was approximately four times higher than that in the liver $(6.26 \mu \mathrm{g} / \mathrm{wet} \mathrm{g})$. The characteristics accumulation of $\mathrm{Hg}$ in liver and $\mathrm{Cd}$ in kidney has been reported by many workers for other species of marine mammals from different localities. ${ }^{1 ~ 6), 9 ~ 17)}$ Correlation coefficients among the metals in all the three tissues were calculated to see if there was any relationship between the metals, and the results are shown in Table II. The concentrations of $\mathrm{Fe}, \mathrm{Pb}, \mathrm{Ni}, \mathrm{Cd}$ and $\mathrm{Hg}$ gave a positive correlation and these concentrations gave a negative one to the concentration of $\mathrm{Mn}, \mathrm{Zn}$ and $\mathrm{Cu}$ except for the positive correlation between $\mathrm{Cd}$ and $\mathrm{Zn}$ in the kidney.

The literature concerning heavy metals, particularly $\mathrm{Hg}$, in seals is extensive, ${ }^{1 \sim 6,15 \sim 17,26,37)}$ but information on the levels in small toothed cetacean is very sparse. The levels of $\mathrm{Fe}$ and $\mathrm{Hg}$ in striped dolphin from Kawana, Japan, ${ }^{37)}$ West Indies, $^{34)}$ and Western Mediterranean ${ }^{33)}$ are in a similar range to ours. Most of the metal levels in striped dolphin also agree with those of harbour porpoises, a beluga whale and a bottlenose whale. ${ }^{6,26)}$ However, $\mathrm{Cd}$ levels in the muscle, liver and kidney of striped dolphins were one or two orders higher than those of harbour porpoises and a beluga whale, and also significantly higher compared with those $(<0.2 \mu \mathrm{g} /$ wet $\mathrm{g})$ in seals such as harbour seal, $\left.{ }^{4}\right)$ common seal ${ }^{25)}$ and ringed seal. ${ }^{7)}$ Such a high Cd level in the striped dolphin is explained by the fact that they feed 
Table I. Heavy Metals ( $\mu \mathrm{g} /$ wet $\mathrm{g}$ ) in Muscle, Liver and Kidney of STRIPED Dolphin, S. coeruleoalba

\begin{tabular}{|c|c|c|c|c|c|c|c|c|c|}
\hline & \multirow{2}{*}{$(\mathrm{N})^{a}$} & \multicolumn{2}{|c|}{ Muscle } & \multirow[b]{2}{*}{$(\mathrm{N})^{a}$} & \multicolumn{2}{|c|}{ Liver } & \multirow[b]{2}{*}{$(\mathrm{N})^{a}$} & \multicolumn{2}{|c|}{ Kidney } \\
\hline & & $\begin{array}{l}\text { Range } \\
\text { Mean }\end{array}$ & $\mathrm{CV} \%$ & & $\begin{array}{l}\text { Range } \\
\text { Mean }\end{array}$ & $\mathrm{CV} \%$ & & $\begin{array}{l}\text { Range } \\
\text { Mean }\end{array}$ & $\mathrm{CV} \%$ \\
\hline $\mathrm{Fe}$ & (59) & $\begin{array}{c}47 \sim 222 \\
159\end{array}$ & 20.8 & (57) & $\begin{array}{c}55.8 \sim 95.5 \\
215\end{array}$ & 44.4 & (30) & $\begin{array}{c}39.6 \sim 267 \\
143\end{array}$ & 30.3 \\
\hline $\mathrm{Mn}$ & (59) & $\begin{array}{c}0.15 \sim 0.46 \\
0.27\end{array}$ & 23.0 & (57) & $\begin{array}{c}1.30 \sim 6.71 \\
3.18\end{array}$ & 31.9 & (30) & $\begin{array}{c}0.45 \sim 1.32 \\
0.82\end{array}$ & 26.7 \\
\hline $\mathrm{Zn}$ & (59) & $\begin{array}{c}6.86 \sim 20.4 \\
11.4\end{array}$ & 21.5 & (57) & $\begin{array}{c}26.5 \sim 109 \\
44.5\end{array}$ & 29.7 & (30) & $\begin{array}{c}22.8 \sim 41.2 \\
30.1\end{array}$ & 15.5 \\
\hline $\mathrm{Cu}$ & (59) & $\begin{array}{c}1.28 \sim 3.37 \\
2.04\end{array}$ & 17.5 & (57) & $\begin{array}{c}3.57 \sim 15.2 \\
8.09\end{array}$ & 23.1 & (30) & $\begin{array}{c}1.46 \sim 6.05 \\
3.13\end{array}$ & 40.0 \\
\hline $\mathrm{Pb}$ & (59) & $\begin{array}{c}0.04 \sim 0.26 \\
0.18\end{array}$ & 40.1 & (57) & $\begin{array}{c}0.03 \sim 0.64 \\
0.22\end{array}$ & 65.9 & (30) & $\begin{array}{c}0.01 \sim 0.71 \\
0.17\end{array}$ & 99.4 \\
\hline $\mathrm{Ni}$ & (59) & $\begin{array}{c}0.04 \sim 0.25 \\
0.14\end{array}$ & 36.3 & (57) & $\begin{array}{c}0.05 \sim 0.49 \\
0.22\end{array}$ & 47.4 & (30) & $\begin{array}{c}0.07 \sim 0.63 \\
0.22\end{array}$ & 76.3 \\
\hline $\mathrm{Cd}$ & (59) & $\begin{array}{c}0.01 \sim 0.25 \\
0.10\end{array}$ & 64.2 & (57) & $\begin{array}{c}0.04 \sim 11.1 \\
6.26\end{array}$ & 37.0 & (30) & $\begin{array}{c}0.06 \sim 69.6 \\
24.8\end{array}$ & 65.2 \\
\hline $\mathrm{Hg}$ & (51) & $\begin{array}{c}0.46 \sim 15.7 \\
7.02\end{array}$ & 57.9 & (45) & $\begin{array}{c}1.70 \sim 485 \\
205\end{array}$ & 67.5 & (20) & $\begin{array}{c}0.91 \sim 17.6 \\
8.71\end{array}$ & 69.7 \\
\hline
\end{tabular}

a Number of samples analyzed.

on squid in which the $\mathrm{Cd}$ concentration is extraordinarily high. ${ }^{32,35)}$

Moreover, $\mathrm{Pb}(>2 \mu \mathrm{g} /$ wet $\mathrm{g})$ in the liver of California sea lion, ${ }^{3)}$ elephant seal ${ }^{7)}$ and common seal, ${ }^{24)}$ and $\mathrm{Fe}(200 \sim 5000 \mu \mathrm{g} /$ wet $\mathrm{g})$ in the liver of weddell seal, leopard seal, crabeater seal and dugong exceeded significantly the concentrations in our striped dolphins. Hepatic $\mathrm{Fe}$ in marine mammals is stored as hemosiderin which is considered to accumulate as a result of excessive $\mathrm{Fe}$ intake. ${ }^{7,38)}$ Seals live inshore where occasional exposure to high $\mathrm{Pb}$ pollution will accumulate a high level of $\mathrm{Pb}$, and conversely, striped dolphins live offshore in a low level of $\mathrm{Pb}$.

Frequency distribution of metal concentrations in muscle, liver and kidney

A wide variation $\left(\mathrm{CV}^{\circ}\right)$ in all metal concentrations of striped dolphins was observed in the liver and kidney, and $\mathrm{Pb}, \mathrm{Ni}, \mathrm{Cd}$ and $\mathrm{Hg}$ concentrations in the muscle also varied widely (Table I). The frequency distribution of the metal concentrations in the muscle, liver and kidney are shown in Fig. 1. Here the data are combined for both males and females, the skewness of concentration distribution being measured by Fisher's measure $(g)$.

The pattern of frequency distribution differs slightly from an ordinary bell-shaped normal distribution, has a tailing to the right for most of the metals, and to the left for both the muscular $\mathrm{Fe}$ and hepatic $\mathrm{Cd}$. To examine the frequency distribution pattern, cumulative frequency was plotted on probability paper (Fig. 2). A straight line was obtained on logarithmic probability paper and this indicates that the concentrations of most the metals examined obey a log-normal distribution. Plots of $\mathrm{Cd}$ concentrations in the muscle are shown in Fig. 2, as an example.

The frequency distribution of heavy metal concentrations in marine mammals has not been previously reported. Ting et $a .^{29)}$ have reported that the frequency distribution of trace elements in two species of marine fish and one marine algae was long-normal. Giesey et $a l .{ }^{30)}$ have examined the frequency distribution of concentrations of $\mathrm{Cd}, \mathrm{Cr}, \mathrm{Cu}, \mathrm{Fe}$ and $\mathrm{Zn}$ in the whole bodies of five fresh water species of fish taken from an inpoundment in South Carolina, USA, and demonstrated that the 
Table II. Correlation Matrix of: Age, Body Length and Weight $v s$.

Metal Concentration; Metal vs. Metal in the Muscle, Liver AND KIDNEY OF STRIPEd Dolphin, $S$. coeruleoalba

\begin{tabular}{|c|c|c|c|c|c|c|c|c|c|}
\hline & & $\mathrm{Fe}$ & $\mathrm{Mn}$ & $\mathrm{Zn}$ & $\mathrm{Cu}$ & $\mathrm{Pb}$ & $\mathrm{Ni}$ & $\mathrm{Cd}$ & $\mathrm{Hg}$ \\
\hline Age & $\begin{array}{l}\text { M } \\
\text { L } \\
\text { K }\end{array}$ & $\begin{array}{l}0.534^{b} \\
0.277 \\
0.299\end{array}$ & $\begin{array}{c}0.097 \\
-0.406^{b} \\
-0.516^{b}\end{array}$ & $\begin{array}{l}-0.375^{a} \\
-0.582^{b} \\
-0.097\end{array}$ & $\begin{array}{c}0.057 \\
-0.432^{b} \\
-0.446^{b}\end{array}$ & $\begin{array}{l}0.630^{b} \\
0.492^{b} \\
0.117\end{array}$ & $\begin{array}{l}0.480^{b} \\
0.485^{b} \\
0.107\end{array}$ & $\begin{array}{l}0.780^{b} \\
0.398^{b} \\
0.245\end{array}$ & $\begin{array}{l}0.817^{b} \\
0.823^{b} \\
0.687^{b}\end{array}$ \\
\hline $\begin{array}{l}\text { Body } \\
\text { length }\end{array}$ & $\begin{array}{l}\text { M } \\
\text { L } \\
\text { K }\end{array}$ & $\begin{array}{l}0.775^{b} \\
0.375^{a} \\
0.542^{b}\end{array}$ & $\begin{array}{c}0.150 \\
-0.530^{b} \\
-0.591^{b}\end{array}$ & $\begin{array}{l}-0.464^{b} \\
-0.721^{b} \\
-0.129\end{array}$ & $\begin{array}{c}0.033 \\
-0.144 \\
-0.569^{b}\end{array}$ & $\begin{array}{l}0.386^{a} \\
0.386^{a} \\
0.104\end{array}$ & $\begin{array}{l}0.453^{b} \\
0.328^{a} \\
0.157\end{array}$ & $\begin{array}{l}0.548^{b} \\
0.369^{a} \\
0.300\end{array}$ & $\begin{array}{l}0.736^{b} \\
0.722^{b} \\
0.610^{b}\end{array}$ \\
\hline $\begin{array}{l}\text { Body } \\
\text { weight }\end{array}$ & $\begin{array}{l}\text { M } \\
\mathrm{L} \\
\mathrm{K}\end{array}$ & $\begin{array}{l}0.717^{b} \\
0.285 \\
0.493^{b}\end{array}$ & $\begin{array}{c}0.134 \\
-0.503^{b} \\
-0.548^{b}\end{array}$ & $\begin{array}{l}-0.408^{b} \\
-0.706^{b} \\
-0.202\end{array}$ & $\begin{array}{l}-0.029 \\
-0.118 \\
-0.565^{b}\end{array}$ & $\begin{array}{l}0.388^{a} \\
0.397^{a} \\
0.068\end{array}$ & $\begin{array}{l}0.466^{b} \\
0.397^{a} \\
0.115\end{array}$ & $\begin{array}{l}0.579^{b} \\
0.380^{a} \\
0.294\end{array}$ & $\begin{array}{l}0.793^{b} \\
0.732^{b} \\
0.641^{b}\end{array}$ \\
\hline $\mathrm{Fe}$ & $\begin{array}{l}\text { M } \\
\text { L } \\
\text { K }\end{array}$ & & $\begin{array}{c}0.233 \\
-0.400^{b} \\
-0.359^{a}\end{array}$ & $\begin{array}{l}-0.292 \\
-0.305 \\
-0.078\end{array}$ & $\begin{array}{c}0.176 \\
-0.055 \\
-0.424^{b}\end{array}$ & $\begin{array}{l}0.159 \\
0.204 \\
0.115\end{array}$ & $\begin{array}{l}0.289 \\
0.009 \\
0.322^{a}\end{array}$ & $\begin{array}{l}0.412^{a} \\
0.139 \\
0.148\end{array}$ & $\begin{array}{l}0.666^{b} \\
0.170 \\
0.363^{a}\end{array}$ \\
\hline $\mathrm{Mn}$ & $\begin{array}{l}\text { M } \\
\text { L } \\
\text { K }\end{array}$ & & & $\begin{array}{l}0.212 \\
0.611^{b} \\
0.325^{a}\end{array}$ & $\begin{array}{l}0.430^{b} \\
0.353^{a} \\
0.605^{b}\end{array}$ & $\begin{array}{l}-0.049 \\
-0.229 \\
-0.119\end{array}$ & $\begin{array}{l}-0.110 \\
-0.031 \\
-0.129\end{array}$ & $\begin{array}{l}-0.139 \\
-0.104 \\
-0.142\end{array}$ & $\begin{array}{l}-0.129 \\
-0.295 \\
-0.656^{b}\end{array}$ \\
\hline $\mathrm{Zn}$ & $\begin{array}{l}\text { M } \\
\text { L } \\
\text { K }\end{array}$ & & & & $\begin{array}{l}0.137 \\
0.473^{a} \\
0.203\end{array}$ & $\begin{array}{c}-0.155 \\
-0.390^{a} \\
0.243\end{array}$ & $\begin{array}{l}-0.020 \\
-0.291 \\
-0.007\end{array}$ & $\begin{array}{r}-0.217 \\
-0.343^{a} \\
0.528^{b}\end{array}$ & $\begin{array}{l}-0.230 \\
-0.459^{b} \\
-0.049\end{array}$ \\
\hline $\mathrm{Cu}$ & $\begin{array}{l}\text { M } \\
\text { L } \\
\text { K }\end{array}$ & & & & & $\begin{array}{r}-0.082 \\
-0.180 \\
0.292\end{array}$ & $\begin{array}{l}-0.060 \\
-0.062 \\
-0.501^{b}\end{array}$ & $\begin{array}{l}-0.226 \\
-0.182 \\
-0.042\end{array}$ & $\begin{array}{l}-0.054 \\
-0.025 \\
-0.625^{b}\end{array}$ \\
\hline $\mathrm{Pb}$ & $\begin{array}{l}\text { M } \\
\text { L } \\
\text { K }\end{array}$ & & & & & & $\begin{array}{l}0.265 \\
0.510 \\
0.357^{a}\end{array}$ & $\begin{array}{l}0.492^{b} \\
0.242 \\
0.154\end{array}$ & $\begin{array}{l}0.432^{b} \\
0.581^{b} \\
0.051\end{array}$ \\
\hline $\mathrm{Ni}$ & $\begin{array}{l}\text { M } \\
\text { L } \\
\text { K }\end{array}$ & & & & & & & $\begin{array}{l}0.294 \\
0.262 \\
0.129\end{array}$ & $\begin{array}{l}0.444^{b} \\
0.469^{b} \\
0.017\end{array}$ \\
\hline $\mathrm{Hg}$ & $\begin{array}{l}\text { M } \\
\text { L } \\
\text { K }\end{array}$ & & & & & & & & $\begin{array}{l}0.686^{b} \\
0.258^{a} \\
0.391^{a}\end{array}$ \\
\hline
\end{tabular}

a Significant level, $p<0.05$.

b Significant level, $p<0.001$.

M, muscle; L, liver; K, kidney.

log-normal, normal, Weibull and exponential distributions had a best fit to $57,17,26$ and $0 \%$ of the species-element groupings respectively. Taguchi et $a .^{28)}$ have also reported that the frequency distribution of concentrations of $\mathrm{Fe}$, $\mathrm{Zn}, \mathrm{Cd}$ and $\mathrm{Cu}$ in the muscle of dogfish was log-normal.

Our results, examined for eight metals in the muscle, liver and kidney of striped dolphins also showed a log-normal distribution similar to those of the other marine organisms.
Therefore, positive or negative skewness causes some discrepancy in the confidence limits for the mean. To avoid a large error in confidence limits for populations in which the primary deviation from normality is a strongly positive or negative skew, Cochron ${ }^{36)}$ has suggested that the sample size $(n)$ must be large enough so that $n>25 g^{2}$, where $g$ is Fisher's measure of skewness. In accordance with this rule, the number of our samples analysed was large enough for most of the metals, but $\mathrm{Pb}$ 


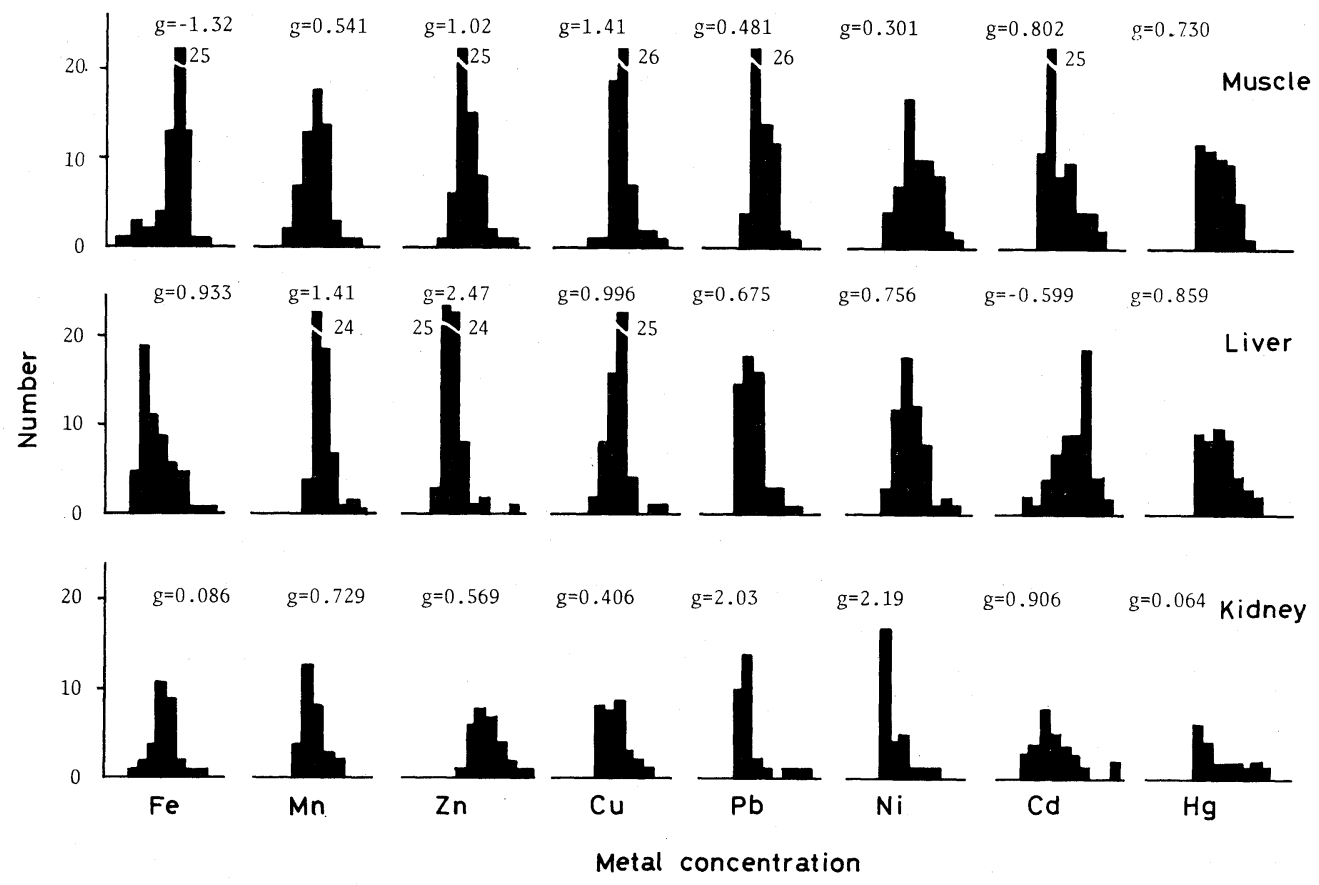

Fig. 1. Frequency Distribution of $\mathrm{Fe}, \mathrm{Mn}, \mathrm{Zn}, \mathrm{Cu}, \mathrm{Pb}, \mathrm{Ni}, \mathrm{Cd}$ and $\mathrm{Hg}$ Concentration in the Muscle, Liver and Kidney of Striped Dolphin.

The data for males and females are combined.

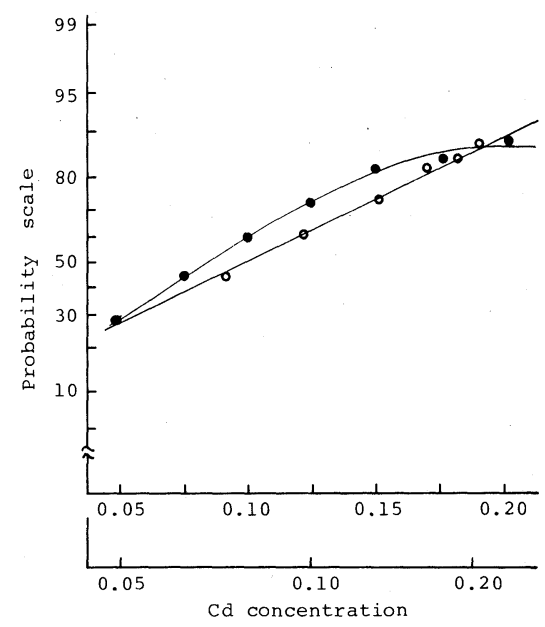

FIG. 2. Cumulative Frequency: Cd Concentration $(\mu \mathrm{g} /$ wet $\mathrm{g})$ in the Muscle, Liver and Kidney of Striped Dolphin.

-- normal scale; ○-, , logarithmic scale.

and $\mathrm{Ni}$ in the kidney showed high skewness $\left(g^{2}=4.12\right.$ for $\mathrm{Pb}$ and 4.80 for $\left.\mathrm{Ni}\right)$. When the distribution of heavy metal concentrations in biology is non-normal and highly skewed, the sample size should be sufficiently large.

\section{Changes of metal concentrations with age and sex}

Significant positive correlation of the metal concentrations with age for striped dolphin was found in the muscular $\mathrm{Fe}, \mathrm{Pb}, \mathrm{Ni}, \mathrm{Cd}$ and $\mathrm{Hg}$, in the hepatic $\mathrm{Pb}, \mathrm{Ni}, \mathrm{Cd}$ and $\mathrm{Hg}$, and in the renal $\mathrm{Hg}$, whilst the hepatic $\mathrm{Mn}, \mathrm{Zn}$ and $\mathrm{Cu}$ and the renal $\mathrm{Mn}$ and $\mathrm{Cu}$ were negatively correlated with age $(p<0.001$, Table II). The concentrations of metals in the muscle, liver and kidney are plotted against age (Figs. 3(a) and 3(b)), with the data for males and females being separately plotted.

Remarkable differences in most of the metal concentrations in the muscle, liver and kidney were observed between the ages of $0 \sim 1$ year (pup) and the older specimens (immature and mature). The concentrations of $\mathrm{Fe}, \mathrm{Pb}, \mathrm{Ni}, \mathrm{Cd}$ and $\mathrm{Hg}$ were higher in the latter than the former, and those of $\mathrm{Mn}, \mathrm{Zn}$ and $\mathrm{Cu}$, except for $\mathrm{Mn}$ and $\mathrm{Cu}$ in the muscle and $\mathrm{Zn}$ in the 

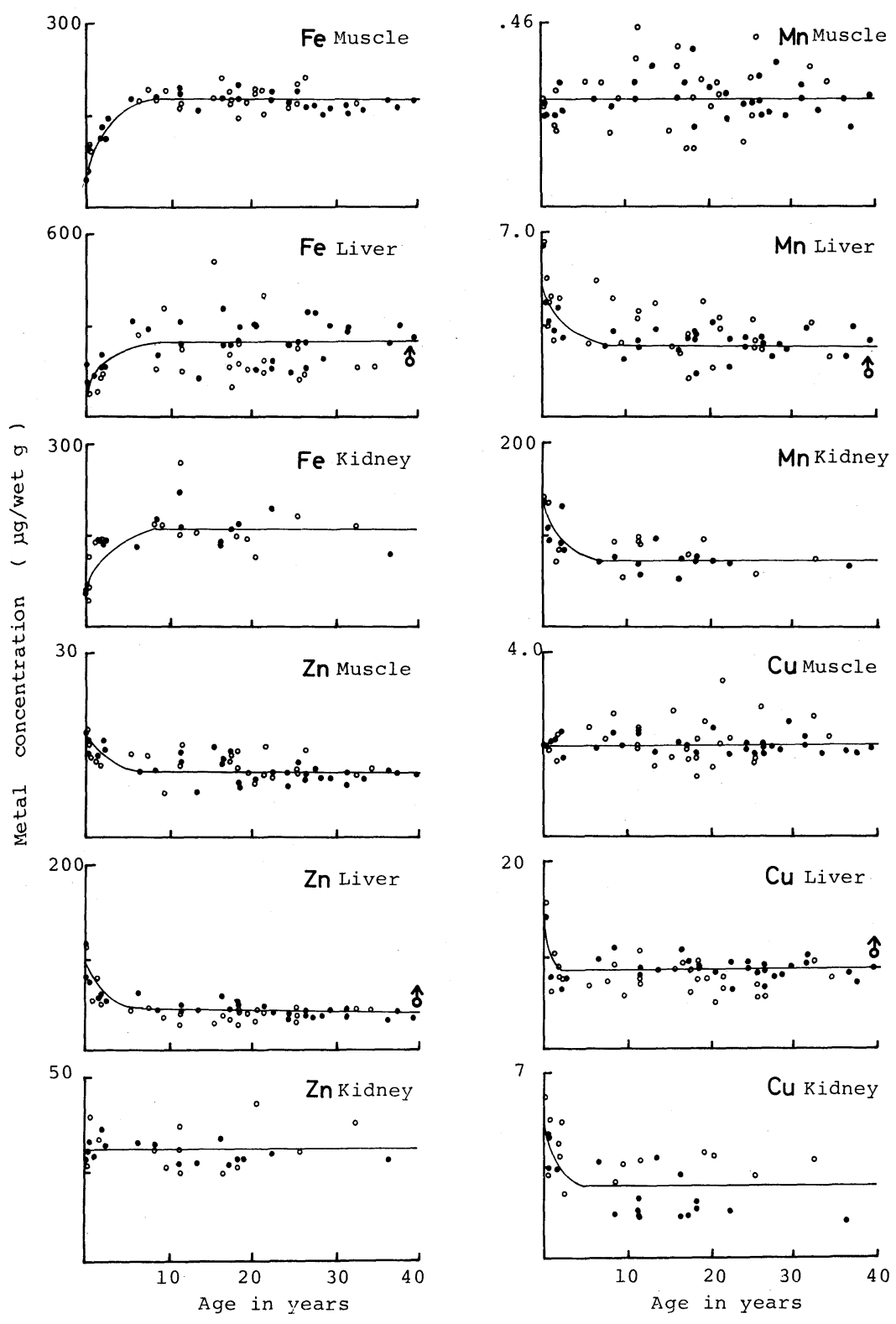

FIG. 3(a). Relationships between the Concentration of $\mathrm{Fe}, \mathrm{Mn}, \mathrm{Zn}$ and $\mathrm{Cu}$ in Muscle, Liver and Kidney, and the Age for Striped Dolphin.

, male; $\bigcirc$, female.

kidney, were higher in the pup. After the rapid change of metal concentrations in pups, the values of $\mathrm{Mn}, \mathrm{Zn}$ and $\mathrm{Cu}$ in immature and mature dolphins remain relatively unchanged, but those of $\mathrm{Fe}, \mathrm{Pb}, \mathrm{Ni}, \mathrm{Cd}$ and $\mathrm{Hg}$ characteristically change with age.

The concentration of $\mathrm{Fe}$ in the muscle in- creased with age until 8 years and thereafter remained constant. A similar tendency also was observed with $\mathrm{Fe}$ in the liver and kidney. The concentrations of $\mathrm{Pb}, \mathrm{Ni}$ and $\mathrm{Cd}$ in the muscle, liver and kidney increased with age until 1 year, and then remained constant through 1 to 18 years. After about 18 years, 

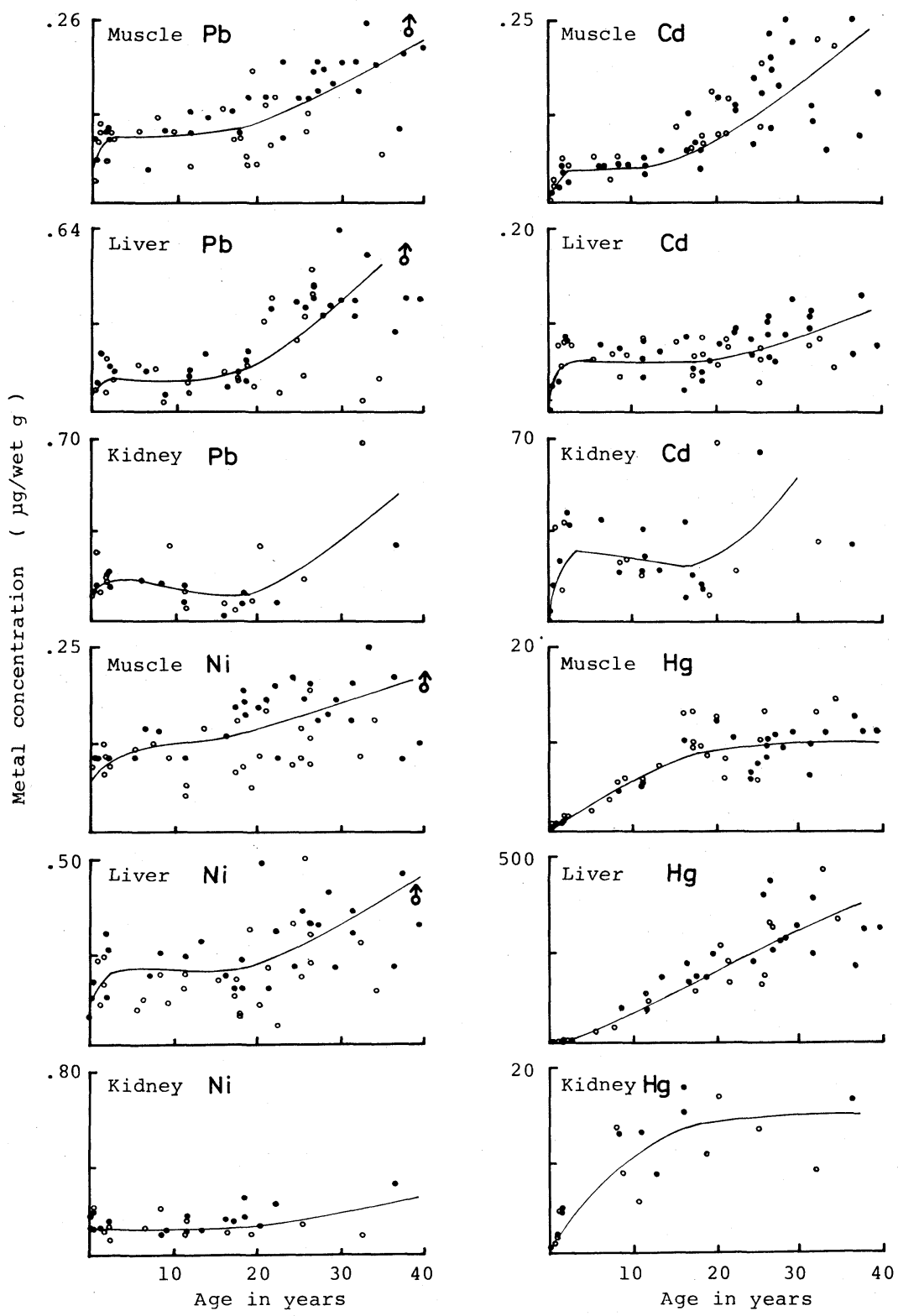

FIG. 3(b). Relationships between the Concentration of $\mathrm{Pb}, \mathrm{Ni}, \mathrm{Cd}$ and $\mathrm{Hg}$ in Muscle, Liver and Kidney, and the Age for Striped Dolphin.

, male; $\bigcirc$, female.

the concentration of $\mathrm{Pb}, \mathrm{Ni}$ and $\mathrm{Cd}$ further increased with age. A steady increase of $\mathrm{Hg}$ concentration in the liver against age during the whole life span was observed, whereas $\mathrm{Hg}$ in the muscle and kidney reached a plateau after about 18 years.

The increase of body length and weight of the striped dolphin ceases at about 8 and 18 years respectively (Fig. 4, discussed in detail later), the weaning and maturity ages being $0 \sim 1$ and 8 years respectively. ${ }^{21)}$

A fast change of metal concentration from birth up to 1 year indicates that particular metals such as $\mathrm{Pb}, \mathrm{Ni}$ and $\mathrm{Cd}$ are transferred via 

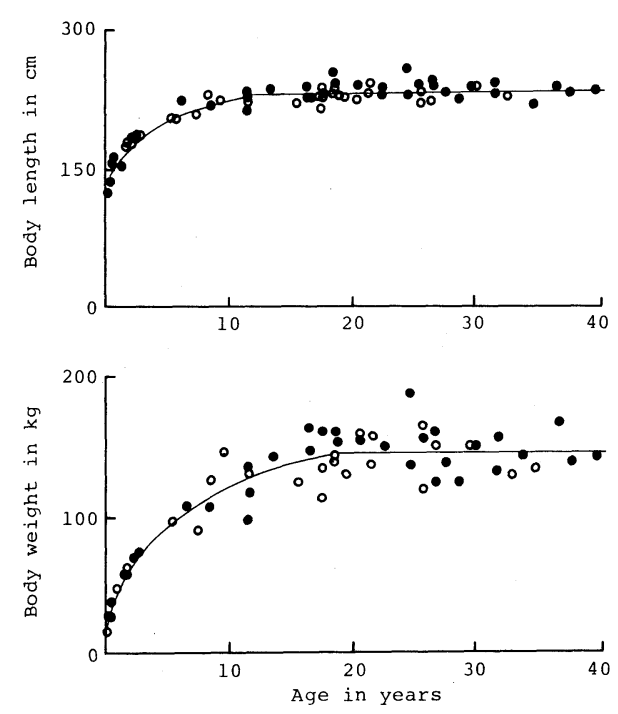

FIG. 4. Relationships between the Body Length and Weight, and the Age for Striped Dolphin.

, male; $\bigcirc$, female.

milk from the mother to her pup. The plateau of the concentrations of $\mathrm{Pb}, \mathrm{Ni}$ and $\mathrm{Cd}$ during $1 \sim 18$ years is explained by physical dilution from the increase in body weight. $\mathrm{Hg}$ did not show such similar dilution effects as $\mathrm{Pb}, \mathrm{Ni}$ and $\mathrm{Cd}$ and this implies a higher absorption rate of $\mathrm{Hg}$ in the digestive tract of striped dolphin and a larger persistence of $\mathrm{Hg}$ than those of other metals. Moreover, a plateau in the concentration of $\mathrm{Hg}$ in the muscle and kidney comes earlier than that in the liver. This indicates a longer biological half-life of $\mathrm{Hg}$ in the liver.

Sexual differences in the metal concentration of striped dolphins are not particularly great (Figs. 3(a) and 3(b)). The concentrations of muscular $\mathrm{Pb}$ and $\mathrm{Ni}$ and hepatic $\mathrm{Fe}, \mathrm{Zn}, \mathrm{Cu}$, $\mathrm{Pb}$ and $\mathrm{Ni}$ were higher in mature male than in mature female, although the hepatic Mn concentration in female was higher than that in male. Furthermore, the concentration of metals in $8 \sim 25$ year females varied more widely than that in males and this probably reflects such reproductive activities as parturition and lactation.
Relationships between body length, weight and metal concentration

There were also some significant positive or negative correlations for metal levels against body length and weight. The concentrations of $\mathrm{Fe}, \mathrm{Mn}, \mathrm{Zn}$ and $\mathrm{Cu}$ in the muscle, liver and kidney showed a high correlation with body length, high with body weight and slight with age. In the case of $\mathrm{Pb}, \mathrm{Ni}, \mathrm{Cd}$ and $\mathrm{Hg}$, however, the correlation with age was always stronger than those with body length and weight (Table II).

The concentration of $\mathrm{Fe}$ in the muscle was proportional to the body length, roughly to the cube root of the body weight, and slightly higher in female than male (Fig. 5). Similar results were obtained on the concentrations of $\mathrm{Fe}, \mathrm{Mn}$ and $\mathrm{Zn}$ in the liver and kidney. This is understandable by the regression equation between the body length and weight which shows $\mathrm{BW}=2.19 \times 10^{-5} \mathrm{BL}^{2.88} \quad\left(r^{2}=0.968\right){ }^{38)} \quad$ The concentration of $\mathrm{Hg}$ in the muscle, liver and kidney also correlated with the body length and weight, higher in female than in male, although it showed strong positive skewness with larger size. Similar results (not shown) were found for $\mathrm{Pb}, \mathrm{Ni}$ and $\mathrm{Cd}$ in the muscle and liver. Plots of $\mathrm{Hg}$ concentration in the liver to the body length and weight are shown in Fig. 6, as an example.

Although $\mathrm{Hg}$ concentration in marine mammals as well as many fish is known to increase with age and size, clear tendencies for other metals have not been established. The correlation of $\mathrm{Fe}, \mathrm{Mn}, \mathrm{Cu}$ and $\mathrm{Cd}$ concentrations to the age and size of harbour seal ${ }^{4)}$ and dugong ${ }^{7)}$ agree well with our results for striped dolphin.

However, no significant correlation of $\mathrm{Pb}$ and $\mathrm{Ni}$ concentrations with age and size was observed for harbour seal ${ }^{4)}$ and dugong. ${ }^{7)}$ These papers also showed that the concentration of $\mathrm{Zn}$ in the liver and kidney of dugong positively correlated with the age, while a specific increase of $\mathrm{Zn}$ concentration in harbour seal was not found. In our striped dolphins, $\mathrm{Pb}$ and $\mathrm{Ni}$ correlated with age and $\mathrm{Zn}$ showed a negative correlation against age. 

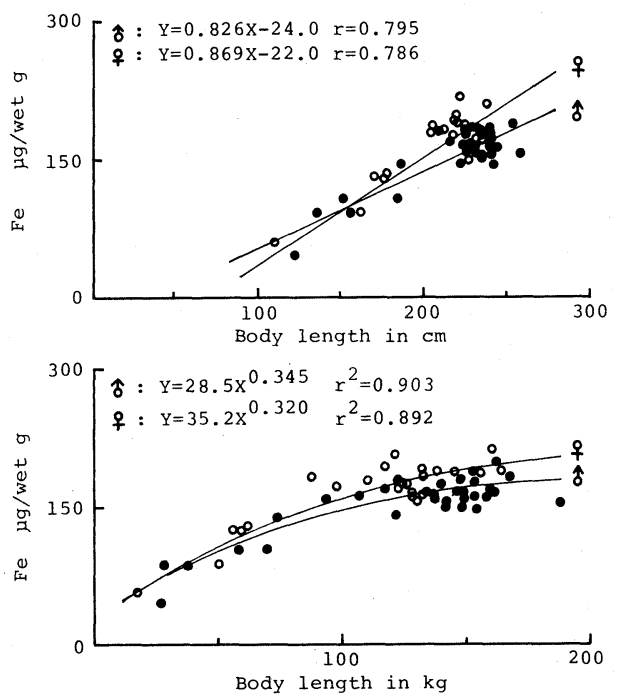

FIG. 5. Relationships between the Concentration of Fe in Muscle and the Body Length and Weight for Striped Dolphin.

, male; $\bigcirc$, female.
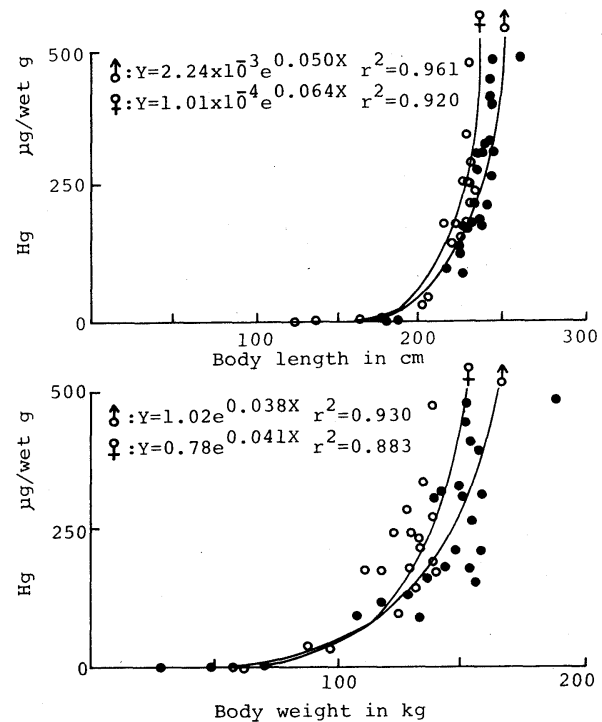

FIG. 6. Relationships between the Concentration of $\mathrm{Hg}$ in Liver and the Body Length and Weight for Striped Dolphin.

, male; $\bigcirc$, female.

This difference may be due to the smaller sample sizes of young harbour seals and dugongs compared with ours, because the pup of striped dolphin contained relatively high $\mathrm{Zn}$ in the liver and low $\mathrm{Pb}$ and $\mathrm{Ni}$ in the muscle, liver and kidney.

Studies by Olsson ${ }^{37)}$ on northern pike, Esox lucius L., are of interest since he found that fish of the same size but of different ages (as a measure of exposure time) had similar $\mathrm{Hg}$ levels. He found also that males had significantly greater $\mathrm{Hg}$ levels than females. Gaskin et $a l^{6)}$ have found clear correlations of $\mathrm{Hg}$ concentration with age in the muscle, kidney, cerebrum and liver of harbour porpoises. They also found that $\mathrm{Hg}$ levels, except in the liver, were less well-correlated with weight and body length than with age, and not significantly correlated with weight and length within the same age classes. Our results here agree well with the results on harbour porpoises ${ }^{6}$ but not with those on the northern pike. ${ }^{37)}$ Such correlation of metal concentration to body length, weight and age indicates that the metabolic turnover (correlated with size) is more important than age or exposure time in determing the levels of $\mathrm{Fe}, \mathrm{Mn}, \mathrm{Zn}$, and $\mathrm{Cu}$, and that the age or exposure time is a dominant factor for accumulation of $\mathrm{Pb}, \mathrm{Ni}, \mathrm{Cd}$ and $\mathrm{Hg}$ in marine mammals.

Acknowledgments. Specimens were collected through the cooperation of the fishermen's unions at Kawana and Taiji. We are greatly indebted to Messrs. Y. Torikai and $\mathrm{K}$. Kouno for helping in the dissection of samples and analysis, and to Mr. N. Oka for helping with computation and statistical analysis. This work was supported in part by Grants-in-Aid for Scientific Research (Project No. 343056) from the Ministry of Education, Science and Culture of Japan and by the Toyota Foundation (80-1123).

\section{REFERENCES}

1) S. Arima and K. Nagakura, Bull. Jpn. Soc. Sci. Fish., 45, 623 (1979).

2) H. W. Braham, Environ. Pollut., 5, 253 (1973).

3) D. R. Buhler, R. R. Claeys and B. R. Mate, J. Fish. Res. Board Can., 32, 2391 (1975).

4) H. E. Drescher, U. Harms and E. Huschenbeth, Mar. Biol., 41, 99 (1977).

5) D. E. Gaskin, K. Ishida and R. Frank, J. Fish. Res. Board Can., 29, 1644 (1972).

6) D. E. Gaskin, K. I. Stonefield, P. Suda and R. Frank, Arch. Environ. Contam. Toxicol., 8, 733 (1979).

7) G. R. W. Denton, H. Marsh, G. E. Heinsohn and C. Burdon-Jones, Mar. Biol., 57, 201 (1980). 
8) D. L. Stoneburner, Sci. Total Environ., 9, 293 (1978).

9) T. Hamanaka, H. Kato and T. Tsujita, Res. Inst. N. Pac. Fish., Hokkaido Univ., Spec. Vol., 547 (1977).

10) A. V. Holden, Rapp. p.-v. Reun. Cons. int. Explor. Mar., 169, 353 (1975).

11) A. V. Holden, Mammal Rev., 8, 53 (1978).

12) J. H. Koeman, W. H. M. Peeters, P. S. Tjioe and J. J. M. De Joeij, TNO-News, 27, 570 (1972).

13) J. H. Martin, P. D. Elliott, V. C. Anderlini, D. Girvin, S. A. Jacobs, R. W. Risenbrough, R. L. Delong and W. G. Gilmartin, Mar. Biol., 35, 91 (1976).

14) P. J. H. Reijinders, Netherlands J. Sea Res., 14, 30 (1980).

15) J. H. Koeman, W. S. M. Van de Ven, J. J. M. DeGoeij, P. S. Tjioe and J. L. Van Haaften, Sci. Total Environ., 3, 279 (1975).

16) D. E. Sergeant and F. A. J. Armstrong, J. Fish. Res. Board Can., 30, 843 (1973).

17) T. G. Smith and F. A. J. Armstrong, J. Fish. Res. Board Can., 32, 795 (1975).

18) N. Miyazaki and M. Nishiwaki, Sci. Rep. Whales Res. Inst., 25, 265 (1974).

19) K. Honda, R. Tatsukawa and T. Fujiyama, Agric. Biol. Chem., 46, 3011 (1982).

20) N. Miyazaki and M. Nishiwaki, Sci. Rep. Whales Res. Inst., 26, 227 (1974).

21) T. Kasuya, N. Miyazaki and W. H. Dawbin, Sci. Rep. Whales Res. Inst., 26, 157 (1974).

22) N. Miyazaki, Y. Fujise and T. Fujiyama, Sci. Rep. Whales Res. Inst., 33, 27 (1981).

23) U. Harms, H. E. Drescher and E. Huschenbeth, Meeresforschung, 26, 153 (1978).

24) D. E. Gaskin, G. J. D. Smith, P. W. Arnold, M. V.
Louisy, R. Frank, M. Holdrinet and J. W. McWade, J. Fish. Res. Board Can., 31, 1235 (1974).

25) D. Viale, Ann. Inst. Oceanogr., 54, 5 (1978).

26) J. H. Koeman, W. H. M. Peeters, C. H. M. Kondstääl-Hol, P. S. Tjioe and J. J. M. DeGoeij, Nature, 245, 385 (1973).

27) K. Honda and R. Tatsukawa, Achiv. Environ. Contam. Toxicol., in press.

28) T. Hamanaka, T. Itoo and S. Mishima, Mar. Poll. Bull., 13, 57 (1982).

29) T. M. Roberts, P. B. Heppleston and R. D. Roberts, Mar. Poll. Bull., 7, 194 (1976).

30) R. A. MacDonald, "Hemochromatosis and Hemosiderosis," ed. by Charles C. Thomas, Springfield, Illinois, 1966, p. 374.

31) R. Y. Ting and V. R. Vega, "The Nature of the Distribution of Trace Elements in Longnose Anchovy, Anchoa lamprotaenia Hildebrand, Antarctic Thread Herring, Opisthonema oglinum LaSueur, and Alga, Vdotea flabellum Lamuouroux," in Symposium on Radioecology, ed. by D. J. Nelson and F. C. Evans, USAEC CONF-670503, 1967, pp. $527 \sim 534$.

32) J. P. Giesey, Jr. and J. G. Wiener, Trans. Am. Fish. Soc., 106, 393 (1977).

33) M. Taguchi, K. Yasuda, S. Toda and M. Shimizu, Mar. Environ. Res., 2, 239 (1979).

34) W. G. Cochran, "Sampling Techniques," 2nd Ed., John Wiley and Sons, Inc., New York, 1963, p. 413.

35) N. Miyazaki, Sci. Rep. Whales Res. Inst., 29, 21 (1977).

36) M. Olsson, Ambio, 5, 73 (1976).

37) T. Taguchi and J. Ui, Kagaku, 52, 168 (1982).

38) Unpublished data. 